\title{
MIS SEMINAR AND THE USE OF ADVISORY BOARD AS AN EFFECTIVE EDUCATIONAL PRACTICE IN RELEVANCY
}

\author{
Asghar Sabbaghi, Indiana University South Bend, sabbaghi@iusb.edu \\ Ganesh Vaidyanathan, Indiana University South Bend, gvaidyan@iusb.edu
}

\begin{abstract}
Advisory Boards have the potential to play a critical role in developing partnerships between business schools and the business community and contribute to the relevance of business curricula. This study will examine the experience of a university that has created an active advisory board for a graduate MIS program and involved the board members in curriculum revision and along with faculty members in conducting a capstone seminar. The capstone seminar may be viewed as meld of "best practices" in IT management from the view-point of a diversified portfolio of healthcare, public and private university, banking, aerospace, manufacturing, home appliance, and automotive industries. The capstone seminar captures key MIS elements of technology and business and is incorporated as the highest quality educational experience in business. This partnership brings effective and collaborative relevance in education between research scholars, senior industry executives, and students. The amalgamation of industrial knowledge, professional perspectives, content relevance, and up-to-date coverage of topics effectuate high academic expectations monitored through multiple student deliverables.
\end{abstract}

Keywords: Advisory Board, Best Practice, Graduate Capstone Seminar, Relevance, MIS Education

\section{INTRODUCTION}

Management Information Systems (MIS) is one of the few interdisciplinary fields of study that integrates both technology and business knowledge. MIS curriculum across the nation must be revised continually to meet the challenging needs of the Information Age economy [4].

The Bureau of Labor Statistics has estimated that more than 1 million high-tech workers are projected to be needed by 2014 [2]. To meet the demands, a large number of major business schools have been redefining themselves as customer oriented, and reorienting their curricula to be more relevant and better connected to their business communities. The Association to Advance Collegiate Schools of Business (AACSB International) established "relevance" as its highest priority [1] for business school curricula and confirmed that:

"The relevance of business curricula cannot be separated from pedagogy. Preparation for the rapid pace of business cannot be obtained from textbooks and cases, many of which are outdated before they are published. Students must learn to use technology for managerial and strategic purposes through action-learning and technology-enhanced pedagogy, and faculty must be equipped to guide them in such learning. Relevance also relates to diversity, yet the composition of students and faculty in many traditional programs does not reflect that of the business world."

Some observers, including Peter Drucker, have been critical of the schism between typical business school curricula and learning experiences, and requisite management skills [1]. They have proposed more "clinical" content of curricula and greater business familiarity among faculty members who import their experiences into the classroom. Outward-facing curricula and experiential education can create the critical intersection between classroom and business learning that keeps faculty and students connected to rapidly changing business models. Yet business clinicians rarely control the design and approval of curricula. Finally, the schism between curricula and practice raises questions about staffing models focused on the "researcher as teacher" in business schools. An expanded staffing approach that accommodates the clinical model would require reassessment of the second-class status of nontraditional teachers, many of whom may be a source of rich industry experience brought into the classroom.

Traditionally, graduates from business schools do not get involved in providing schools with feedback and therefore there has been a gap between business school graduates and business community needs of skilled employees. Business schools need to establish partnerships between the business community and themselves. An advisory board consisting of business leaders can play a key role in this process. In the past, 
intellectual resources of a business school have not been sufficiently integrated into partnership setting within the business community; each has worked in relative isolation.

An advisory board in our view has high potential in playing a central role to bring faculty, students, graduates, and the business community to a partnership alliance and induce a synergy of resources both in the business community and the business school. The School of Business and Economics at Indiana University South Bend serves as a major unit of a comprehensive public university, serving North Central Indiana and South Western Michigan. We have established an advisory board for the MIS department that consists of Chief Information officers (CIOs) and MIS directors of regional companies. This board has been very active and has made a number of contributions to the Master of Science in Management Information Technologies (MS-MIT) including participation in MS-MIT seminar capstone course.

To bring relevance into MIS curricula, we have adopted a capstone course which invites MIS leaders from the community to interact with the students. This study will examine this capstone course experience along with outcome assessments. In the following section, we discuss the profile of the school and the characteristics of the graduate program. In the next section, we discuss the curricula and the role of advisory board in curriculum development as well as their participation in conducting the capstone seminar.

\section{SCHOOL PROFILE AND PROGRAM DEVELOPMENT}

The School of Business and Economics is a major unit of a comprehensive public university with over 7,500 students, located in a metropolitan area of northern Indiana, serving north central Indiana and southwestern Michigan that has a population of approximately 250,000. The School received its AACSB reaccredidation in 1988-89 and again in 1999-2000. In fact, this is the only public university accredited by AACSB-International in the area. At the undergraduate level, the school offers concentrations in Management and Administration, Accounting, Economics, Finance, Marketing, Marketing/Advertising, Management Information Systems, and Human Resources Management. At the graduate level, it offers the Master of Business Administration (MBA), Master of Science in Accounting (MSA), and Master of Science in Management Information Technologies (MS-MIT).
The graduate degrees are carefully tailored to the needs of students who currently hold professional or managerial positions. The MS-MIT program, the first of its kind in region, is an interdisciplinary program cooperatively offered by the School of Business and Economics and the College of Liberal Arts and Sciences (Department of Computer and Information Sciences). The program is uniquely designed to provide computing/managerial skills to its graduates and enables them to effectively plan and manage complex information technologies for their firms and successfully advance their manufacturing/service organizations. The program was developed from the result of a survey conducted among prospective students and employers in the region.

In 1997 the Decision Sciences faculty conducted a survey among people who have a degree earned in Business \& Economics or Mathematics \& Computer Science. The faculty mailed 2,926 surveys to those graduates who live in the counties immediately surrounding the region and received 285 responses. An analysis of responses made to the survey showed strong interest in the program among potential students. More than $93 \%$ of respondents agreed or strongly agreed with the statement, "The regional business community needs more people who really understand how to apply information technology in a business setting." More than $92 \%$ of respondents agreed or strongly agreed with the statement, "I would benefit from having a solid education in both business and computing topics." Over $87 \%$ of respondents believed that a Master's Degree in MIS could lead to a better job. About $77 \%$ of respondents claimed that they would be interested in a Master's Degree in MIS. The survey also showed a widespread belief among survey respondents that their employers would both support and reward those employees who earned a Master's Degree in MIS.

At the same time, the faculty also conducted a survey of potential employers of the proposed program's graduates. Using published information from the Chamber of Commerce in local communities, the faculty compiled a list of manufacturing firms employing more than 25 people in the counties surrounding and including the area. Nonmanufacturing firms were not included in the data we had and therefore are not represented in our results. An analysis of responses to the survey showed strong support for the proposed degree among potential employers of its graduates. Thirty-one of the respondents $(91 \%)$ agreed or strongly agreed with the statement, "Employees in my firm would benefit from having a solid education in both business and computing topics." Over $88 \%$ felt that the (regional) 
business community needed more people who really understand how to apply information technology in a business setting. About $82 \%$ of the respondents believed that the proposed Master's Degree in MIS would be appropriate training for a manager of information technology. Other opinions indicated willingness to support and reward employees who earn such a degree, as well as some interest in serving as a member of an advisory board for the program.

In addition to their opinions about the proposed degree, respondents to the survey also provided estimates of the number of employees in their firms engaged in MIS activities and of their past and future hiring of MIS-related employees. Most of the firms responding to the survey employed several people charged with MIS managerial duties. Twenty firms $(59 \%)$ had 1 or 2 employees who manage MIS, while another 8 firms (24\%) employed 3 or 4 people in this way. 23 firms $(68 \%)$ had from 1 to 5 employees engaged in MIS technical duties, while another 4 firms $(12 \%)$ had between 6 and 10 employees carrying out such work. Seventy-four percent (25) of the responding firms claimed to have hired between 1 and 5 employees to perform MIS duties during the last 2 years. Sixty-eight percent (23) of the responding firms expected to hire from 1 to 5 new employees into MIS positions. One firm (3\%) expected to hire more than 6 , but fewer than 10 , employees to fulfill MIS jobs in the next 2 years.

\section{MIS Curricula with Computer Science Integration}

MIS graduates will integrate technologies and applications to provide better access to corporate data and they need technical skills in telecommunications, data access and management, decision support systems, and firm-specific technologies [5]. Therefore, it is imperative to provide the students with both business and technical or computer sciences knowledge. Computer science involves the design of computer architecture, programming languages, algorithms and data structures, operating systems, software engineering, databases, information retrieval, artificial intelligence, and robotics [3]. MIS focuses on incorporation of information technologies to ensure the availability of accurate and appropriate information in the right form to decision makers and help firms successfully achieve their goals [6].

The Decision Sciences faculty in cooperation with faculty from Computer Science Department developed the program and its curriculum, secured approval from the curriculum committees at various stages and the relevant authorities in the University system process, and implemented in the fall of 2000. The MIS program is a joint venture between the Business School and the Computer Science Department and is unique with respect to collaboration and gaining synergy of intellectual resources.

More than the technical and business knowledge, the students need to understand the current business scenarios and understand how to apply their knowledge in "real-life." In addition to the business and technology learning, the students need an ability to effectively apply technology in seeking solutions to business problems [5]. Therefore, to create this unique opportunity and environment, the Decision Sciences faculty identified CIO/MIS Directors of major companies in the area, and invited them for membership to the Advisory Board. An advisory Board was created that consists of CIOs and MIS directors from the area companies. The advisory board consists of Chief Information officers (CIOs) and MIS directors of regional companies representing Honeywell, Bosch, Whirlpool, NIBCO, A M General, Biomet, I/N Tek and I/N Kote, Memorial Health System, Notre Dame, IU South Bend, Teachers Credit Union, and 1st Source Bank. This situation is captured in Figure 1, which illustrates this model.



Figure 1. Business School/Business Community Alliance Model

The advisory board has made a number of contributions to the relevance of the curriculum and the program. The Board has suggested some curricular changes to the curriculum for Graduate and Undergraduate MIS Programs that was found to be very beneficial. For example, students in MS-MIT Program had to take two capstone seminar courses at the end of the program. The Board suggested changing one of the seminars to an elective course so that students can combine MIT skills and knowledge with an area of their own strength and interest that may be technical, managerial, marketing, human resource management, leadership, communication skills, or others. That suggestion was implemented and found to be very beneficial. The Board has advised the faculty and administration to incorporate and teach SAP, the leading edge Enterprise Resource 
Planning (ERP) software. The School became a member of the SAP University Alliance program with nominal maintenance fee, and incorporated the software into the MIS curriculum. This allowed school to incorporate SAP $\mathrm{R} / 3^{\mathrm{TM}}$ throughout the curriculum in the graduate/undergraduate courses and has become an asset to the MIS program.

More important, the Board participates in conducting the capstone seminar course. We will discuss this feature of the MIS program and the involvement of the advisory board in more detail in the following section.

\section{RELEVENCY AND CAPSTONE COURSE}

Modern-day MIS programs must provide students with a strong background in program analysis and design techniques and an in-depth understanding of computer technology and application that afford students the opportunity to apply the knowledge through realistic IS projects focused on business problems [5]. In addition to the technical skills, MIS curriculums should focus on developing interpersonal and business skills [5]. The MS-MIT Program is the first of its kind in the region, with regard to technical and business mix and as a joint cooperative effort between the business school and the computer science department from the College of Liberal Arts and Science. Moreover, while the admission standards are based on GMAT/GRE, academic qualifications and professional experience, the program offers flexibility to various candidates who are admitted to the program. One has to complete Mathematics and Statistics, basic business, business core, and Business and Applied Computing Core before taking Advanced Business Core courses. These courses in turn are prerequisite to the capstone seminar.

\section{Capstone Seminar and Advisory Board}

As discussed earlier, students are required to take a seminar course as the capstone of the program when they complete their course work. Students have the option to write a thesis supervised by a Committee of three faculty members and present it to a group of MIS faculty/graduate students, or take a seminar course (enrollment limited to 6-8 students) offered once a year. The seminar is scheduled once a week for two and half hours for fifteen weeks during the semester.

The purpose of this seminar course is to integrate the knowledge students gained in the program with the advanced business application topics and implementation issues covered in class. It is a seminar with a significant emphasis on engaging students in meaningful discussion about the selected topics. This is not a "Special Topics" class but instead a class that tries to relate the courses that students have completed to what is going on in the real business world. In short, it is a capstone course for the students in this program and coordinated by a senior faculty member. To this end, a number of high level IT executives from the advisory board, representing various industries, are invited to collaborate with designated faculty members in conducting this seminar. Each session then is conducted by a board member and facilitated by a faculty member who has taught in the Program. The topics of seminar for each session are developed by the faculty and the board member paired for that session and the reading material will be provided to students in advance. Students are expected to read the material in advance and actively participate in discussion and reflect in that session.

Students are evaluated in three areas: class participation, class reflection, and course paper. Class reflection is evaluation by the seminar coordinator and the instructor of each session. While the actual session may last for about two hours, the rest of the time left to students themselves to reflect about the discussion of the night. After each session, thus, students are to truly reflect, not simply summarize, on the evening's discussion. It is expected that thinking (i.e., 'reflecting') will take student from 30 to 45 minutes before he/she actually start to write the reflection. The amount of time may go down after they do the first two or three. It is expected that student should consider integrating the knowledge he/she gained in various phases of the Program with topics discussed during the class session. Furthermore, they must complete the reflection using computer labs before they leave campus and email it to the seminar coordinator and to instructor for the evening.

Students are expected to integrate the session discussions and move toward bringing the program together. They are to take the reflection in each week and (1) develop an integrating theme that may focus on one subject that recurred through the sessions, or (2) use the reflections as a way to organize many diverse topics. Their report will be graded for form as well as the content, so it should be free from spelling and grammatical errors. It is expected a truly professional presentation. The faculty members will participate in the grading process. To this end, each student must send the seminar coordinator and a group of designated faculty members a one to two- 
page proposal explaining/outlining what they would like to do. Once the proposal approved, student would start writing the report. They are expected to make their report as professional as possible. The report will be graded not only on the basis of writing presentation of their observation/ understanding/reflection, but also on the basis of their writing style and how well and professionally they have crafted the entire report.

Over the last two years the board members have actively engaged in conducting this seminar. Each week, a board member paired with a faculty member conduct the seminar. Thus, an executive seminar leader is matched with a faculty member from the Program to facilitate the seminar and share perspectives and experiences. They formulate seminar topics, identify and select reading materials, and collaborate on seminar preparation. Seminar students apply the theories and concepts learned from various courses in the program to practical business situations they face in the seminar thereby integrating their knowledge through analyzing IT management issues. We consider this seminar as a best practice in management education. It captures key elements that the Decision Science faculty members believe are incorporated in the highest quality educational experiences in business including collaboration between research scholars and senior industry executives, blending of academic and professional perspectives, relevance of content, up-to-date coverage of topics, high academic expectations monitored through multiple student deliverables. This seminar has been offered in this form during the spring of 2004 for the first time, and later with much gained experience offered recently during the fall semester of 2005. Each time, two sessions were assigned to organizational structure and final exam, and thirteen sessions were assigned to seminar conductors/facilitators and full discussion coverage. In each session four to six topics made the central theme of discussion by the board member, faculty member and students. Based on the outcome assessment it was indeed a successful experience and we consider this pedagogy and advisory board participation in this capstone seminar a success and one of the best practice in management education. We found students highly motivated in seminar participation, in learning, in reflection, in writing semester paper, and in students-end-of-semester evaluation. For example, one of the students noted that if he could give a view from 50,000 feet of what he believed were the main points of learning in the seminar series the highlights would be the following:
- IT leaders must have a good understanding of the business they serve and the world they compete in. They need to understand what information technology can do, but do not have to be able to personally implement every minute detail of the technical solution.

- The world will change around you and you must be forward looking to be able to avoid or mitigate possible negative changes or threats that might come toward you.

Due to the positive outcomes, one of the Board members has volunteered to financially sponsor this seminar series for the next three years so that we can enhance the impact of this high quality seminar and our educational program to our business community.

\section{CONCLUSION}

This study has examined the experience of a university that has created an active advisory board for a graduate MIS program and their involvement as board members in curriculum revision and in conducting a capstone seminar along with the faculty. The capstone seminar course provides the students relevancy to their MIS education. The advisory board alliance brings effective and collaborative relevance in education between research scholars, senior industry executives, and students. We are planning next year to open this seminar to a limited number of targeted individuals in IT executives/managerial professionals as well.

\section{REFERENCES}

1. AACSB International (August 2002), Management Education at Risk. Report from the Management Education Task Force.

2. Bureau of Labor Statistics. (November 2005). Occupational employment projections to 2014, Monthly Labor Review.

3. Denning, P. J., Comer, D., Gries, D., Mulder, M., Tucker, A., Turner, J., \& Young, P. (1989). Computing as a discipline. Computer, 63-69.

4. Ehie, I.C. (2002). Developing a Management Information Systems (MIS) curriculum: Perspectives from MIS practitioners. Journal of Education for Business, 77(3), 151-158.

5. Trauth, E.M., Farwell, D.W., Lee, D. (1993). The IS expectation gap: Expectations versus academic preparation. MIS Quarterly, 17(3), 293-307.

6. Turban, E., Leidner, D., McLean, E., Wetherbe, J. (2006). Information Technology for management. John Wiley: Hoboken, N. 